\title{
Pemberdayaan Masyarakat Melalui Manajemen Zakat Fitrah Pada Masa Pandemi Di Desa Motolohu Kecamatan Helumo Kabupaten Bolaang Mongondow Selatan
}

\author{
${ }^{1}$ Dian Adi Perdana, ${ }^{2}$ Samsul Mohi \\ 1,2IAIN Sultan Amai Gorontalo, IAIN Sultan Amai Gorontalo \\ 1,2dianadiperdana@iaingorontalo.ac.id; mohisamsul@gmail.com
}

\begin{abstract}
Zakat is to purify the rights that a person has and separate the rights of others contained therein, so that it can provide benefits to others. The Indonesian government has regulated the management of zakat in UU no. 38 of 1999 about Zakat Management, regulations are made to facilitate the community in the process of collecting, managing and distributing zakat. This research discusses the management of zakat fitrah in Motolohu Village, Bolaang Mongondow Selatan Regency during the pandemic. The condition of the community is disturbed in paying zakat fitrah during the pandemic, especially in the economic sector. Researchers examined the management of zakat fitrah carried out by the government and zakat officials in Motolohu Village during the pandemic, the collection process, distribution and distribution of zakat fitrah during the pandemic, as well as the benefits of zakat fitrah for the community. This study uses a descriptive qualitative approach with various questions to the informants to get answers to social problems about community empowerment through zakat fitrah management in Motolohu Village during the pandemic. Data collection techniques used observation, interviews and documentation to several sources. The data that has been obtained are then analyzed in order to obtain the results presented in the form of conclusions. The results of research on the collection, management and distribution in Motolohu Village were carried out with different techniques. Collection of zakat, zakat administrators visit the houses of people who want to pay zakat. Zakat payments are divided into 3 levels, the process of collecting zakat is carried out optimally by paying attention to people's income. The public is advised to donate Rp. 5,000 / person. Distribution of zakat fitrah, officers distribute zakat fitrah equipped with health protective equipment. The benefits of zakat fitrah that are obtained by muzakki in Motolohu Village are the implementation of amaliyah which can still be applied by giving to those who have the right, especially in a pandemic situation.
\end{abstract}

Keywords: Community Empowerment, Zakat Management, Zakat Fitrah

\begin{abstract}
Abstrak
Zakat adalah mensucikan hak-hak yang dimiliki seseorang dan memisahkan hakhak orang lain yang terkandung di dalamnya, sehingga dapat memberikan manfaat bagi orang lain. Pemerintah Indonesia telah mengatur pengelolaan zakat dalam UU no. 38 Tahun 1999 tentang Pengelolaan Zakat, peraturan dibuat untuk memudahkan masyarakat dalam proses pengumpulan, pengelolaan dan penyaluran zakat. Penelitian ini membahas tentang pengelolaan zakat fitrah di Desa Motolohu Kabupaten Bolaang Mongondow Selatan pada masa pandemi. Kondisi masyarakat terganggu dalam membayar zakat fitrah di masa pandemi, khususnya di bidang ekonomi. Peneliti mengkaji pengelolaan zakat fitrah yang dilakukan oleh pemerintah dan pengelola zakat di Desa Motolohu pada masa pandemi, proses pengumpulan, penyaluran dan penyaluran zakat fitrah pada
\end{abstract}


masa pandemi, serta manfaat zakat fitrah bagi masyarakat. Penelitian ini menggunakan pendekatan deskriptif kualitatif dengan berbagai pertanyaan kepada informan untuk mendapatkan jawaban atas permasalahan sosial tentang pemberdayaan masyarakat melalui pengelolaan zakat fitrah di Desa Motolohu pada masa pandemi. Teknik pengumpulan data menggunakan observasi, wawancara dan dokumentasi ke beberapa sumber. Data yang telah diperoleh kemudian dianalisis untuk memperoleh hasil yang disajikan dalam bentuk kesimpulan. Hasil penelitian tentang pengumpulan, pengelolaan dan pendistribusian di Desa Motolohu dilakukan dengan teknik yang berbeda. Pengumpulan zakat, pengelola zakat mengunjungi rumah-rumah orang yang ingin membayar zakat. Pembayaran zakat dibagi menjadi 3 tingkatan, proses pengumpulan zakat dilakukan secara optimal dengan memperhatikan pendapatan masyarakat. Masyarakat disarankan untuk berdonasi sebesar Rp. 5.000 / orang. Penyaluran zakat fitrah, petugas pendistribusian zakat fitrah dilengkapi dengan alat pelindung diri kesehatan. Manfaat zakat fitrah yang diperoleh para muzakki di Desa Motolohu adalah pelaksanaan amaliyah yang masih dapat diterapkan dengan memberikan kepada yang berhak terutama dalam situasi pandemi.

\section{Kata Kunci: Pemberdayaan Masyarakat, Pengelolaan Zakat, Zakat Fitrah}

\section{PENDAHULUAN}

Dunia yang kita hidup didalamnya, kini sedang mengalami kesedihan yang mendalam, beribu manusia telah berguguran baik dikarenakan menyelamatkan orang lain dan mempertahankan diri sendiri dari serangan virus yang sedang merebak hingga detik ini. Virus ini begitu menakutkan, hingga setiap manusia wajib menjaga diri sendiri untuk menyelamatkan orang di sekitarnya. Penggunaan masker, tidak saling bersentuhan hingga memberikan jarak kedekatan minimal satu meter. Hal-hal tersebut wajib dilakukan sebagai upaya menjaga kesehatan diri agar selalu dapat beraktifitas sebagaimana mestinya seperti bekerja, membeli bahan makanan dan kebutuhan seharihari. Dunia yang sedang bersedih ini berdampak besar ke segala sektor kehidupan manusia, tak terkecuali yang bersinggungan dengan nilai-nilai agama.
Islam sebagai salah satu agama terbesar di duniapun melalui para tokoh muslim di masyarakat menghimbau untuk tetap melakukan aktifitas sesuai protokol kesehatan yang diperintahkan oleh pemerintah masing-masing. Aktifitas sholat, berzakat hingga haji pun dijaga ketat demi keselamatan bersama, seperti member jarak satu meter di setiap shaf dalam sholat, menghimpun dan mendistribusikan dana zakat tanpa mengundang kerumunan serta ditundanya kegiatan haji dan umroh. Segala aktifitas dan rutinitas keagamaan yang sering dilakukan pun semakin terbatas. Virus covid-19 ini telah menerjang dan menyerang seluruh elemen masyarakat dari barat hingga timur dunia, bukan hanya Islam tapi seluruh agama wajib membatasi diri dalam setiap kegiatan yang biasanya dilakukan. Kita tahu bahwa setiap kejadian pasti ada hikmahnya atau manfaat di dalamnya, salah satunya adalah memperkuat silaturahmi internal keluarga dengan selalu berkumpul. 
Silaturahmi yang telah lama tidak terjalin karena kesibukan masingmasing individu, kini menjadi dekat tanpa sekat, seperti pendidikan melalui daring membuat setiap anak selalu bertemu kedua orang tuanya bahkan perhatian tercurahkan secara maksimal guna membina emosional anak kepada orang tua atau orang yang lebih tua menjadi lebih baik. Silaturahmi memberikan banyak manfaat, salah satunya adalah memperpanjang umur setiap yang menjalaninya. Pertemuanpertemuan yang dialami akan membangun kekuatan dan ikatan emosional antar individu lebih kuat, salah satu aktifitas yang membangun emosional dengan pertemuan adalah berzakat. Dengan berzakat, setiap individu akan lebih peka dan tanggap terhadap perubahan sosial, ekonomi serta keagamaan di sekitarnya, yang kaya akan membantu yang miskin, yang kuat akan membantu yang lemah dan kekurangan harta. Islam mengatur itu semua dengan berbagai ketegasan dalam ayat-ayat Al-Qur'an untuk memecahkan berbagai permasalahan sosial masyarakat.

Zakat merupakan aktifitas keagamaan dalam Islam untuk mensucikan hak yang dimiliki seseorang dan memisahkan hak-hak orang lain yang terdapat di dalamnya, sehingga dapat memberikan manfaat kepada sesama baik lahir maupun batin. Sejalan dengan itu, zakat adalah aktivitas memberikan harta tertentu yang diwajibkan Allah SWT dalam jumlah dan perhitungan tertentu untuk diserahkan kepada orang-orang yang berhak (Mubarok and Fanani 2014). Pemerintah Indonesia sendiri telah mengatur pengelolaan zakat dalam Undang-undang No. 38 Tahun 1999 tentang Pengelolaan Zakat,
Undang-undang No. 17 Tahun 2000 tentang Perubahan Ketiga Undangundang No. 7 tahun 1983 tentang Pajak Penghasilan, Keputusan Menteri Agama (KMA) Nomor 581 tahun 1999 dan Keputusan Direktur Jenderal Bimbingan Masyarakat dan Urusan Haji Nomor D tahun 2000 tentang Pedoman Teknis Pengelolaan Zakat (Gurning and Ritonga 2015). Peraturanperaturan di atas akan lebih memudahkan masyarakat Indonesia dalam proses penghimpunan, pengelolaan hingga pendistribusian zakat dari masyarakat untuk masyarakat.

Zakat dapat ditunaikan di waktu tertentu dan tanpa waktu atau bebas, zakat yang ditunaikan dalam dalam waktu tertentu sering dikenal dengan zakat fitrah, yakni zakat yang wajib ditunaikan bagi umat muslim pada bulan Ramadhan yang diiringi dengan ibadah puasa di bulan tersebut. Menurut Sabiq dalam Jumadin, Zakat fitrah adalah zakat yang diwajibkan karena berbuka dari bula n Ramadhan (Lapopo 2017). Yusuf Qardhawi menjelaskan zakat fitrah terjadi karena sebab diwajibkannya berbuka puasa (futhur) pada bulan suci Ramadhan (Qardawi 1999). Zakat fitrah sebagai amaliyah rutin dan wajib dilaksanakan menjadi ibadah khusus dan penting bagi setiap manusia, karena memiliki berbagai manfaat bagi lahir dan batin manusia yang menunaikannya. Bulan suci ramadhan bukan hanya sebagai masa balas dendam terhadap perbuatan-perbuatan terdahulu, akan tetapi sebagai masa intropeksi diri seorang hamba kepada Tuhannya yang selalu memberikan kemudahan dan keberkahan terhadap yang dimiliki dan dititipkan. 
Penelitian ini membahas pengelolaan zakat fitrah di masa pandemi dengan latar belakang wilayah non padat penduduk yakni salah satu desa di Sulawesi Utara, tepatnya di Desa Motolohu, Kabupaten Bolaang Mongondow Selatan. Kesadaran masyarakat dalam menunaikan zakat fitrah menjadi faktor utama, apalagi di masa sulit seperti ini, yang telah diketahui bahwa hampir seluruh sektor kehidupan mengalami depresi atau penurunan secara drastis, khususnya pada bidang ekonomi. Zakat fitrah yang merupakan solusi konkret dalam menyegarkan ekonomi masyarakat secara perlahan dan dalam waktu singkat, akan mampu memberikan dampak positif bagi setiap umat. Beberapa penelitian terkait zakat fitrah sebagai solusi sosial di masa pandemik menjelaskan yakni salah satu sarana yang dapat meringankan beban sosial yakni zakat, yang merupakan solusi terjitu dalam memberikan pertolongan pertama dalam memenuhi kebutuhan sehari-hari (Saputra 2020).

Berkaitan dengan menunaikan zakat fitrah di masa pandemik ini, terdapat pula beberapa ketentuan penunaian zakat fitrah yakni perihal ta'jil az-zakah. Indonesia yang merupakan pengikut madzhab syafi'iyyah, beberapa ulama mengatakan bahwa zakat fitrah boleh dilakukan sejak awal Ramadhan sebagai solusi sosial dalam menghadapi covid-19 ini, dikarenakan kondisi masyarakat yang terdampak dan membutuhkan bantuan secara ekonomi (Abadi 2020). Seiring dengan hal tersebut, maka diperlukan pengelolaan zakat fitrah yang cepat, tepat dan optimal sebagai solusi terbaik dalam mengentaskan kemiskinan di Indonesia. Pengelolaan zakat fitrah tentunya mengedepankan perencanaan, pengorganisasian, pergerakan dan pengawasan yang maksimal dengan memperhatikan aturan-aturan yang sudah diatur dalam Islam. Sinergitas masyarakat dan pemerintah sangat diperlukan sebagai solusi utama dalam menangani musibah covid-19 ini dengan memperhatikan tujuan utama dalam kehidupan sosial yakni dhoruriyah, hajiyah dan tahsiniyah, sehingga aktifitas akan pulih kembali (Kadir et al. 2020).

Pertolongan pertama dalam meringankan musibah masal, keringanan dalam menunaikan zakat fitrah di masa pandemi covid-19 dengan memperhatikan dhoruriyah, hajiyah dan tahsiniyah masyarakat menjadi fokus utama dalam pengelolaan zakat fitrah sebagai pemberdayaan masyarakat di segala sektor guna mendukung ekonomi dan memenuhi kebutuhan sehari-hari. Penelitian ini berlokus di Motolohu, Kecamatan Helumo, Kabupaten Bolaang Mongondow Selatan yang mayoritas beragama Islam, dengan mengkaji manajemen zakat fitrah yang dilakukan oleh pemerintah serta petugas zakat di Desa Motolohu selama masa pandemi, mengkaji proses penghimpunan, penyaluran dan penyaluran zakat fitrah selama masa pandemi, serta mengkaji manfaat zakat fitrah bagi masyarakat Desa Motolohu saat menghadapi cobaan di masa pandemi ini.

\section{METODE PENELITIAN}

Penelitian ini menggunakan pendekatan kualitatif dengan metode deskriptif dengan berbagai pertanyaan kepada narasumber untuk memperoleh jawaban dari persoalan sosial tentang 
pemberdayaan masyarakat melalui pengelolaan zakat fitrah di Desa Motolohu pada masa pandemi. Adapun penelitian ini menggunakan teknik pengumpulan data yakni observasi dan wawancara ke beberapa narasumber primer dan sekunder, serta dokumentasi dengan melihat dokumen organisasi di desa tersebut. Data-data yang telah diperoleh kemudian dianalisa guna memperoleh hasil yang disajikan dalam bentuk kesimpulan dari jawaban-jawaban persoalan tersebut (Arikunto 2014). Penelitian ini dilakukan selama masa pandemi untuk memperoleh berbagai informasi yang dapat menjadi referensi bagi peneliti selanjutnya di bidang yang sama, khususnya bidang ekonomi sosial dan kemasyarakatan.

\section{HASIL DAN PEMBAHASAN}

\section{Manajemen Zakat Fitrah di Desa Motolohu}

Keberadaan Desa Motolohu tidak terlepas dan bermula dari perkembangan kehidupan masyarakat setempat, di mana Desa Motolohu merupakan salah satu desa yang ada di Provinsi Sulawesi utara, tepatnya di Kabupaten Bolaang Mongondow Selatan di Kecamatan Helumo. Dahulu desa ini masih tergabung dengan desa tetangga yakni Desa Pangia. Rencana pemekaran desa ini atas inisiatif dari toko-toko masyarakat. Para toko masyarakat mengajukan proposal terkait dengan pemekaran desa, masyarakat yakin dan percaya bahwa Desa Motolohu siap menjadi desa yang berkembang dan mandiri. Setelah ditetapkan sebagai desa baru yang terdiri dari tiga dusun saja. Tahun 2008, desa ini diresmikan yang pertama kali dipimpin oleh bapak Almarhum Arianto Islaku sebagai Sangadi atau kepala desa pertama Desa Motolohu.

Lama kelamaan pemukiman ini mulai berkembang, masyarakat asli dan masyarakat lain mulai berdatangan dan mulai menetap di desa ini. Seiring berjalannya waktu desa Motolohu terus berkembang sesuai dengan keadaan dan dinamikanya sampai seperti sekarang. Adapun struktur kepemerintahan Desa Motolohu saat ini yakni Narlis Mohi sebagai Sangadi/Kepala Desa, Abd Rahman Kaharu S.Pd.I. sebagai Sekretaris Desa, Hadija Ali sebagai Kepala Dusun 1, Zulkarnain Mohi sebagai Kepala Dusun 2, Tahrun Kaharu sebagai Kepala Dusun 3, Sumarni Mohulaingo sebagai Kasi Pemerintahan, Samsul Ngilalo sebagai Kasi Kesra Pelayanan, Awin Hurairah sebagai Kaur Umum, dan Dela Islaku Kaur Keuangan.

Pengelolaan zakat di Desa Motolohu tidak terlepas dengan sejarah panjang pengelolaan zakat di Indonesia yakni dana atau harta yang dizakatkan disalurkan muzakku kepada amil zakat atau pengelola zakat, kemudian disalurkan kepada mustahiq untuk pendayagunaan masyarakat baik produktif maupun konsumtif. Dalam pemberdayaan zakat zakat fitrah, bukan hanya dapat dimanfaatkan untuk hal-hal yang bersifat konsumtif, tetapi juga untuk sesuatu yang bersifat produktif. Dengan pemanfaatan zakat untuk kegiatan yang produktif akan memberikan income (pemasukan) bagi para mustahiq dalam kelangsungan hidupnya. Para mustahiq dapat memanfaatkan dana atau harta yang diperoleh untuk meningkatkan pendapatan atau ekonomi keluarga 
melalui usaha produktif (Fitri 2017). Para penerima zakat akan terbantu untuk mendapatkan lapangan pekerjaan yang akan meningkatkan kesejahteraan bagi dirinya dan keluarganya dan selanjutnya berdampak bagi kesejahteraan masyarakat pada umumnya.

Sebelum pemekaran dan menjadi desa yang mandiri, proses pengelolaan zakat sudah berlangsung sejak lama semenjak masih berstatus bagian dari Desa Pangia. Setelah resmi pemekaran, Desa Motolohu akhirnya membentuk sebuah pengurus pengelolaan zakat. Para anggota dari pengurus tersebut adalah pengurus dari lembaga atau pegawai syar'i yang ada di Desa Motolohu yang terdiri dari para imam dan anggotaanggota lain yang siap bertugas dalam mengelola zakat yang ada di Desa Motolohu. Sebelum pemekaran sampai saat ini pengurus dan sistem pengelolaan zakat masih berjalan sebagaimana mestinya. Ada pun struktur pengelolaan zakat desa Motolohu yakni Abd Muthalib Tangahu sebagai Ketua, Ahmad Uno sebagai Bidang 1, Irfan Hundalangi sebagai Bidang 2, serta Tamrin Ali sebagai Bidang 3.

\section{Proses 3P Zakat Fitrah di Desa Motolohu}

Zakat fitrah merupakan zakat wajib yang dikeluarkan balita sampai orang dewasa dan dibayar sekali dalam setahun. Zakat ini dibayarkan dalam bentuk uang tunai maupun beras yang harus dilakukan sebelum batas akhir atau sebelum sholat idul fitri. Standar yang dipakai dalam zakat fitrah 2,5 kg beras dengan harga beras setempat. Proses pembayaran zakat fitrah di Desa
Motolohu sebagian besar memilih pembayarannya dalam bentuk uang tunai. Proses pembayaran Zakat selama Pandemi di Desa Motoloh. Proses 3P yakni terdiri dari Penghimpunan, Pengelolaan dan penyaluran.

Penghimpunan zakat fitrah disesuaikan dengan kebijakan pemerintah pusat maupun pemerintah daerah yakni berupa kebijakan pembatasan untuk mendorong otoritas dan menyesuaikan ketentuan pembayaran dan penyaluran zakat. Selama Pandemik Covid-19 beberapa bulan ini seluruh aktivitas harus dibatasi dan semua pekerjaan harus dikerjakan dari rumah masingmasing mulai dari sekolah, kantor dan lain-lain yang melibatkan banyak orang. Begitu pula dengan sistem pembayaran zakat ada beberapa daerah yang telah melakukan sistem pembayaran melalui layanan Bank sebagai upaya untuk memutuskan mata rantai dari penyebaran Covid-19.

Desa Motolohu melaksanakan penghimpunan zakat dengan pengurus zakat mengunjungi masing-masing dari rumah masyarakat yang hendak membayar zakat. Kebijakan ini telah di sepakati oleh perangkat desa dan seluruh masyarakat Desa Motolohu dengan mempertimbangkan bahwa Desa Motolohu Kecamatan Helumo masih dalam Zona hijau atau $0 \%$ angka penyebaran virus corona. Pemerintah Desa serta petugas zakat fitrah menjelaskan sistem pengelolaan zakat selama Pandemik. Pembayaran zakat terbagi atas beberapa tingkatan, sebagai berikut Orang mampu sebesar Rp.30.000/Jiwa, Sedang atau kalangan menengah sebesar Rp.27.500/Jiwa, serta Orang tidak mampu sebesar Rp.22.500/Jiwa. 
Proses penghimpunan zakat dilakukan dengan maksimal dengan memperhatikan pendapatan masyarakat yang menurun di masa pandemi ini terutama mereka yang berprofesi sebagai petani atau nelayan, oleh karena itu diberikan kesempatan untuk berzakat fitrah dengan tingkatan orang yang tidak mampu. Bagi masyarakat yang bekerja sebagai aparat desa atau pun memiliki took sederhana dapat memilih tingkatan menengah dan ini diperhatikan pula dari harta dan beban atau tanggungan yang dimiliki (seperti hutang). Masyarakat yang sedang kesulitan dalam menafkahi keluarga atau menjadi pengangguran diberi kesempatan berzakat dengan tingkatan orang yang tidak mampu serta dicatat menjadi mustahiq.

Pengelolaan zakat fitrah di Desa Motolahu di masa pandemi ini tetap menjalankannya karena ini kewajiban bagi setiap muslim, bahkan masyarakat bersyukur karena Desa Motolohu masih berada di zona aman selama pandemik covid-19 ini. Seperti yang dijelaskan sebelumnya bahwa Pembayaran zakat terbagi atas beberapa tingkatan, sebagai berikut Orang mampu sebesar Rp.30.000/Jiwa, Sedang atau kalangan menengah sebesar Rp.27.500/Jiwa, serta Orang tidak mampu sebesar Rp.22.500/Jiwa. Hal yang menarik dalam penghimpunan dan pengelolaan zakat fitrah ini bahwa masyarakat dihimbau untuk berinfak sebesar Rp.5.000/Jiwa. Setelah dilakukan penghimpunan, didapati mayoritas masyarakat berinfak dengan rata-rata sebesar Rp.5.000/Jiwa. Pemerintah desa serta pengurus zakat kemudian mendata seluruh masyarakat Motolohu dan memilih masyarakat seperti apa uang berhak mendapatkan zakat tersebut.

Proses penyaluran zakat selama pandemi yang berhak menerima zakat adalah orang-orang yang termasuk ke dalam 8 golongan/asnaf (fakir, miskin, amil, mualaf, hamba sahaya, gharimin, fi sabilillah, ibnu sabil). Akan tetapi, menurut beberapa ulama khusus untuk zakat fitrah mesti didahulukan kepada dua golongan pertama yakni fakir dan miskin. Pendapat ini disandarkan dengan alasan bahwa jumlah/nilai zakat yang sangat kecil sementara salah satu tujuannya dikeluarkannya zakat fitrah adalah agar para fakir dan miskin dapat ikut merayakan hari raya dan saling berbagi sesama umat Islam. Penyaluran zakat fitrah oleh muzakki kepada mustahiq di Desa Motolohu dilakukan dengan cara datang langsung kepada orang-orang yang berhak menerima zakat.

Dalam proses penyaluran zakat fitrah kepada para mustahiq bahwa zakat fitrah masih berjalan dengan baik, tidak mengalami kegaduhan ataupun perselisihan antar individu. Zakat fitrah disalurkan langsung oleh pemerintah desa dan pengurus zakat desa agar dapat berlangsung secara khidmat dan sesuai protokol kesehatan. Proses penyaluran zakat fitrah ini para petugas melakukan penyaluran zakat fitrah dengan dilengkapi APD atau alat pelindung kesehatan seperti masker, sarung tangan dan alat pembersih sekali pakai (tisue). Hal ini dilakukan untuk menjaga serta mencegah penyebaran virus di wilayah desa ini, mayarakat pun merespon baik dengan kondisi dan perlakuan seperti ini, dikarenakan ini adalah bentuk apresiasi dan antisipasi antar individu untuk terus dapat 
beribadah dengan maksimal dan optimal.

Kepedulian antar individu masih terjalin dengan baik, sehingga harta yang diperoleh dapat digunakan untuk memenuhi kebutuhan di hari raya Idul Fitri, para mustahiq pun masih dapat merasakan kebahagiaan seperti yang lainnya. Para mustahiq lebih mengutamakan penggunaan harta zakat fitrah yang diperoleh untuk membeli kebutuhan sehari-hari khususnya makanan dan minuman. Dengan adanya penghimpunan, pengelolaan dan penyaluran zakat fitrah ini, setiap muslim dapat meningkatkan pengetahuan dan menjalankan syariat Islam di masa sulit seperti ini, dan masyarakat serasa tidak mengalami kendala yang berlebihan dalam menunaikan zakat fitrah di Desa Motolohu, Kecamatan Helumo, Kabupaten Bolaang Mongondow Selatan.

\section{Manfaat Berzakat di Masa Pandemi}

Membayar zakat adalah salah satu kewajiban yang harus dilaksanakan oleh seorang Muslim. Islam telah mengatur tata cara pembayaran zakat termasuk harta apa saja yang harus dikeluarkan zakatnya. Secara syariat Islam telah ditetapkan nominalnominal harta yang wajib dizakatkan dan juga waktu untuk menunaikan zakat, bahkan dalam Al-Quran juga telah jelas disebutkan bahwa siapasiapa saja yang berhak menerima pemberian zakat tersebut. Selama pandemik seperti ini mungkin banyak daerah yang membolehkan membayar zakat dengan non uang tunai atau pun beras, mengingat pemerintah juga paham bagaimana ekonomi Indonesia saat ini. Pemerintah Desa Motolohu menetapkan pembayaran zakat fitrah dengan pembayaran dalam bentuk uang tunai, tidak dengan sembako atau produk lainnya.

Berzakat memberikan manfaat kepada muzakki, Allah SWT tidak akan memerintahkan hamba-Nya menjalankan amalan tertentu tanpa tujuan yang jelas dan bermanfaat. Begitu pula soal berzakat. Zakat merupakan ibadah yang tidak hanya membawa kebaikan untuk diri sendiri, tapi juga orang lain. Bisa dibilang, zakat adalah satu-satunya amalan yang mampu memberikan dampak sosial yang luas dan langsung. Adanya zakat memberikan contoh kepada seseorang untuk bersikap ikhlas dan dermawan, sekaligus menciptakan kepedulian terhadap mereka para yatim dan dhuafa, serta fakir miskin. Zakat mempunyai banyak manfaat baik dari sisi sosial maupun keagamaan. Dari sisi keagamaan, mengeluarkan zakat sangat memberikan manfaat bagi muzakki atau orang yang memberikan zakat. Zakat merupakan sarana mendekatkan diri kepada Allah SWT dan bisa meningkatkan keimanan dan ketaatan kepada Allah SWT.

Berzakat dapat menjadi media penolong pertama bagi masyarakat untuk meringankan musibah massal, keringanan dalam menunaikan zakat fitrah di masa pandemi seperi ini dapat diperhatikan dari ketiga hal ini dhoruriyah, hajiyah dan tahsiniyah. Pertama, dhoruriyah diperhatikan dari kondisi yang sedang mencekam saat ini dengan adanya wabah yang menglobal, sehingga masyarakat pun terbatas dalam menjalani aktifitasnya. Kedua, hajiyah bahwa masyarakat memerlukan 
solusi untu kemaslahatan bersama, yang dapat dilakukan dnegan mudah dalam kehidupan dan mengurangi kesulitan maupun kesempitan khususnya dalam berzakat fitrah. Ketiga, tahsiniyah yakni tindakan yang dilakukan dari sebuah solusi yang dihadirkan dapat memberikan kebaikan bagi setiap umat manusia, dalam konteks zakat fitrah yakni dengan mendorong daya beli masyarakat agar perekonomian tetap berjalan.

Selama masa pandemi, ada beberapa manfaat zakat fitrah yang diperoleh para muzakki di Desa Motolohu yakni zakat fitrah sebagai bentuk penyucian diri atau pembersihan diri, amaliyah yang masih terus dapat diterapkan dengan memberi kepada orang yang berhak apalagi di situasi pandemik seperti ini, zakat fitrah sebagai bekal di akhirat, berzakat dapat meningkatkan rasa kasih sayang, simpati dan empati terhadap saudara yang kekurangan, berzakat dapat menghilangkan sifat pelit serta bakhil antar sesama, zakat dapat membantu orang dermawan yang mempunyai sifat mulia berupa kedermawanan dan rasa toleransi yang tinggi terhadap sesama, berzakat sebagai zarana memberikan contoh kepada seseorang bahwa memberi itu sama sekali tidak membuat kita miskin, apalagi di bulan suci ini akan dilipatgandakan, dan berzakat sebagai media menghapus dosa.

Pada masa ini pula, didapati manfaat zakat bagi para mustahiq di Desa Motolohu, apalagi di situasi seperti ini yang mengharuskan seluruh kegiatan dibatasi dan dirumahkan. Sebagian orang mungkin masih terbilang aman karena masih bisa mencukupi kehidupan kita tapi tidak dengan mereka yakni fakir dan miskin. Seperti yang sudah dijelaskan sebelumnya bahwa para mustahiq yang ada di Desa Motolohu sangat berterimakasih dan bersyukur karena masih banyak yang peduli dengan mereka. Keberlangsungan zakat ini dapat meringankan beban ekonomi yang dihadapi, dan tentunya lebih meningkatkan ketakwaan terhadap sang pencipta Allah SWT.

\section{SIMPULAN}

Pengelolaan zakat sudah berlangsung sejak lama semenjak masih berstatus bagian dari Desa Pangia. Setelah resmi pemekaran, Desa Motolohu akhirnya membentuk sebuah pengurus pengelolaan zakat. Para anggota dari pengurus tersebut adalah pengurus dari lembaga atau pegawai syar'i yang ada di Desa Motolohu yang terdiri dari para imam dan anggota-anggota lain yang siap bertugas dalam mengelola zakat yang ada di Desa Motolohu. Proses 3P yakni terdiri dari Penghimpunan, Pengelolaan dan penyaluran di Desa Motolohu dilakukan dengan teknis yang berbeda. Dalam penghimpunan zakat, pengurus zakat mengunjungi masing-masing dari rumah masyarakat yang hendak membayar zakat. Pemerintah Desa serta petugas zakat fitrah menjelaskan sistem pengelolaan zakat selama Pandemik. Pembayaran zakat terbagi atas beberapa tingkatan, sebagai berikut Orang mampu sebesar Rp.30.000/Jiwa, Sedang atau kalangan menengah sebesar Rp.27.500/Jiwa, serta Orang tidak mampu sebesar Rp.22.500/Jiwa. Proses penghimpunan zakat dilakukan dengan maksimal dengan memperhatikan pendapatan masyarakat yang menurun di masa 
pandemi ini. Masyarakat yang sedang kesulitan dalam menafkahi keluarga atau menjadi pengangguran diberi kesempatan berzakat dengan tingkatan orang yang tidak mampu serta dicatat menjadi mustahiq.

Hal yang menarik dalam penghimpunan dan pengelolaan zakat fitrah ini bahwa masyarakat dihimbau untuk berinfak sebesar Rp.5.000/Jiwa. Setelah dilakukan penghimpunan, didapati mayoritas masyarakat berinfak dengan rata-rata sebesar Rp.5.000/Jiwa. Pemerintah desa serta pengurus zakat kemudian mendata seluruh masyarakat Motolohu dan memilih masyarakat seperti apa uang berhak mendapatkan zakat tersebut. Proses penyaluran zakat fitrah, para petugas melakukan penyaluran zakat fitrah dengan dilengkapi APD atau alat pelindung kesehatan seperti masker, sarung tangan dan alat pembersih sekali pakai (tisue). Hal ini dilakukan untuk menjaga serta mencegah penyebaran virus di wilayah desa ini, mayarakat pun merespon baik dengan kondisi dan perlakuan seperti ini, dikarenakan ini adalah bentuk apresiasi dan antisipasi antar individu untuk terus dapat beribadah dengan maksimal dan optimal.

Ada beberapa manfaat zakat fitrah yang diperoleh para muzakki di Desa Motolohu yakni zakat fitrah sebagai bentuk penyucian diri atau pembersihan diri, amaliyah yang masih terus dapat diterapkan dengan memberi kepada orang yang berhak apalagi di situasi pandemik seperti ini, zakat fitrah sebagai bekal di akhirat, berzakat dapat meningkatkan rasa kasih sayang, simpati dan empati terhadap saudara yang kekurangan, berzakat dapat menghilangkan sifat pelit serta bakhil antar sesama, dan berzakat sebagai media menghapus dosa. Serta didapati bahwa para mustahiq yang ada di Desa Motolohu sangat berterimakasih dan bersyukur karena masih banyak yang peduli dengan mereka. Dan juga zakat ini bisa meringankan beban ekonomi yang dihadapi.

\section{DAFTAR RUJUKAN}

Abadi, Khafid. 2020. "HUKUM TA'JIL AZ-ZAKAH KARENA ADANYA PANDEMI COVID-19." Ar-Risalah: Jurnal Keislaman, Pendidikan Dan Hukum Islam 18, no. 2: 193-206. https://doi.org/https:/ / doi.org/1 0.29062/arrisalah.v18i2.390.

Arikunto, Suharsimi. 2014. Prosedur Penelitian: Suatu Pendekatan Penelitian. Rineka Cipta.

Fitri, Maltuf. 2017. “Pengelolaan Zakat Produktif Sebagai Instrumen Peningkatan Kesejahteraan Umat." Economica: Jurnal Ekonomi Islam. https://doi.org/10.21580/econom ica.2017.8.1.1830.

Gurning, H., and H. Ritonga. 2015. "ANALISIS TINGKAT KESADARAN MASYARAKAT KECAMATAN MEDAN BARU DALAM MEMBAYAR ZAKAT." Jurnal Ekonomi Dan Keuangan.

Kadir, Afifuddin, Miftahur Rahman Hakim, Fahmi Syam, and Murdiansah SA Karim. 2020. "PENGUNAAN DANA ZAKAT PADA KORBAN COVID-19 PERSPEKTIF MAQASHID SYARIAH." Al-Tafaqquh: Journal of 
Islamic

Law.

https://doi.org/10.33096/al-

tafaqquh.v1i2.61.

Lapopo, Jumadin. 2017. “PENGARUH

ZIS (ZAKAT, INFAK, SEDEKAH)

DAN ZAKAT FITRAH

TERHADAP PENURUNAN

KEMISKINAN DI INDONESIA

PERIODE 1998 - 2010." Media

Ekonomi.

https://doi.org/10.25105/me.v20i

1.779 .

Mubarok, Abdulloh, and Baihaqi Fanani. 2014. "PENGHIMPUNAN DANA ZAKAT NASIONAL (Potensi, Realisasi Dan Peran Penting Organisasi Pengelola Zakat)." Permana.

Qardawi, Yusuf. 1999. "Hukum Zakat." Mizan, Bandung.

Saputra, Hijrah. 2020. "ZAKAT SEBAGAI SARANA BANTUAN BAGI MASYARAKAT BERDAMPAK COVID-19." AlIjtima $i$ : International Journal of Government and Social Science. https://doi.org/10.22373/jai.v5i2.

549. 